\title{
Education Policy
}

Rebecca Allen

\section{Abstract}

This article summarises the 2010-15 Coalition government's education policy, contrasting their attempts to liberalise education markets with the desire to impose a highly traditional curriculum. The government's quite radical reforms have not been easy to implement, taking place against severe budgetary constraints and a minority Coalition partner with ambitions to improve the educational outcomes of children from low income families. It could be argued that the reforms have been successfully implemented, and there is little prospect of wholesale reversal by any future government. However, their combative approach to reform leaves a demotivated teacher workforce, a possible impending teacher recruitment crisis as the economy recovers, and a tangled web of accountability structures that will need to be resolved.

\section{Introduction}

The Coalition government's education policy could be described as an alliance of libertarian and traditional values, continuing the themes of the 1979-97 Tory governments. To call it a coalition policy might be a stretch; like no other Secretary of State in this government, Michael Gove can lay claim to ownership of the direction and drive for change in the department he ran from 2010 to 2014. ${ }^{1}$

As libertarians, the government set out a policy manifesto to empower parents as consumers, with the rhetoric of Free Schools built round the idea that any person with the will and the support could set up a local school and be funded to do so by the state. The central belief was that market forces, if set free, will improve standards through competition amongst schools offering diversity of pedagogical approaches and ethos. Resulting educational disruption through entry and exit of schools from the market should be hailed as a success rather than a cause for concern.

However, the radical market idea of devolved power to the unit of the school, driven by parent choice, was countered by a rich seam of centralisation resulting from 'traditional values', or at least a traditional view of curriculum and teaching that had to be driven from the central government department.

These libertarian and traditional approaches were implemented by ministers and their advisors who gave the impression that anybody involved in education as it was set - local authorities, teachers and educationalists - was either not up to the job or could not be trusted. Not least because the values of those people were not aligned with the government's view of how to create a 'good' society and economic properity and, left to their own devices, might ignore the call for a classical education. Nothing more emphasises this theology than the controversy over the re-writing of the history syllabus in 2013 as part of wider National Curriculum reforms (DFE, 2013a). The initial proposals for a sequential "narrative of British progress", in the words of Michael Gove, had the air of central direction rather than a trust in devolution.

The constraints of budgetary pressure and accommodation of Liberal Democrat policy significantly shaped this government's programme in education, as elsewhere. Budgetary pressures in a government committed to reducing the deficit left little room for the capital outlay necessary to sustain a significant market entry. The Liberal Democrats hailed new interventions for children from 
disadvantaged families, while controversially dropping their pledge not to increase higher education tuition fees.

\section{Focusing market forces on a traditional schooling agenda}

Proponents of the idea that market forces are the best route to improving the schooling system have recognised that there has been, to date, a weak relationship between deregulation, increasing school choice and raising attainment (Allen and Burgess, 2010). The government's programme of reforms attempts to remedy this in six ways:

1. Reforms to school league tables to ensure that parents are better able to identify school quality;

2. Threats to the survival of underperforming schools through a reformed inspection process and forced takeover of governance and management;

3. The introduction of newly created free schools to enhance parental choice and competition;

4. An increased capacity of schools to control their own operations through academy status;

5. Incentives for all teachers to raise the attainment of the children they teach through mandatory Performance Related Pay schemes; and

6. Reforms to teacher training to ensure the right mix of candidates enter the profession and are trained to suit schools needs.

\section{Measuring school performance}

Reforming league tables is the most straightforward means by which government can influence school curriculum choices, since there is enormous pressure from parents, Ofsted and governing bodies to perform well on these metrics, even where there is little threat of loss of pupils. The initial market-orientated stance of the government was that parents were capable of interpreting data to suit their own interests, so the logical approach was to publish every statistic possible. This included reporting performance statistics separately for children of low, middle and high prior attainment, in line with proposals I published with Simon Burgess (Allen and Burgess, 2011, 2013). This was a rather overoptimistic assessment of the typical parent's data-processing skills and so, not surprisingly, the key measure of five or more $A^{*}-C$ at GCSE, including English and maths, continued to dominate schools' focus.

From 2012 onwards, the traditionalist secondary school curriculum was accelerated through league table reforms. The government identified that many children were not being given the opportunity to study the widely accepted academic broad curriculum of English, maths, two sciences, a humanity subject and a language. They announced that schools would be judged on a binary measure of whether a child had achieved at least a grade $C$ in each of these subjects, labelling it the 'English Baccalaureate' or EBacc.

This began the process of a radical restructuring of the curriculum within many schools, reducing their dependence on arts and vocational subjects, many of which dropped out of performance table measures altogether as the list of accepted equivalents was reduced in line with recommendations by Professor Alison Wolf's review (Wolf, 2011). However, the EBacc indicator gave no incentive for schools to reprioritise their curriculum for those students who stood little chance of gaining a $C$ in these subjects, so the government went further still and from 2015 onwards a new measure called 'Attainment 8' (and its associated 'Progress 8' that accounts for prior achievement) will give points for every child who scores more than a grade $U$ in these subjects (or in computer science). For a government that takes the starting point that this curriculum is appropriate for all children this is a very attractive accountability measure since it incentivises headteachers to ensure 
that all their major departments are effective for children from the top to the bottom of the ability spectrum.

A final set of reforms is still to be implemented, though there is considerable uncertainty about whether this will take place as planned from 2015. GCSE grades will be changed from 1-9 in order to differentiate better between $A$ and $A^{*}$ grades at the upper end. AS levels will be decoupled from the $A$ level and will return to being a separate, stand-alone qualification. These reforms appear to be ideologically driven, not supported by schools, and strongly opposed by universities who have been able to use AS level grades to select applicants.

Primary schools have been subject to considerable change in accountability measures too. An age 6 statutory phonics screening check, which entertainingly includes fake words, ensures that schools are using the approved synthetic phonics approach to teaching children to read. An extension paper was reintroduced for Key Stage two tests to distinguish between the large group of children who were achieving the highest marks in the main paper (about 17 per cent of children were scoring the top mark on the government measure of their combined maths, English and science performance). The government also reintroduced marks for grammar, punctuation and spelling in primary school tests.

Then, responding to criticisms of the ways that the progress of children was monitored throughout English schools via 'Levels', the government decided that Levels should be abandoned and replaced with whatever system for monitoring the schools themselves thought best. Levels did indeed have their problems, and almost nobody supported the way they were being used, but replacing them with nothing is likely to create chaos in a system where teachers need a common language to talk about the standards of children. Indeed, where schools have now devised a new scheme, it is usually Levels in all but name. It remains unclear what primary school assessment will eventually look like, with the possibility of radical reform to both entry (Foundation Stage Profile) and exit (Key Stage two) tests in the near future.

\section{School inspection}

The government turned itself to school inspection reforms first through the appointment of Sir Michael Wilshaw as Chief Inspector of Education, Children's Services and Skills on 1 January 2012. Sir Michael had a pedigree in state education, as a teacher for more than 40 years and over half of that time as a headteacher in London, most recently of the famous Mossbourne Community Academy in Hackney.

Sir Michael had presided over the amazing turnaround of fortunes of a state school within a transformed local authority and city's education system. So he perhaps understandably had a belief that there were 'no excuses' for difficulties in any school in the country. He announced changes to the inspection regime from September 2012 by declaring that "Satisfactory is no longer satisfactory". Schools that had previously breathed a sigh of relief as they had passed an inspection would now be labelled 'requires improvement' and given clear instructions by Ofsted about what they need to improve. They would have a monitoring regime that paralleled that given to failing schools: checking action plans, monitoring progress and re-inspecting within a shorter period of time. If a school merited the new designation of 'requiring improvement' for the third time consecutively, instead it would be likely to be found inadequate at that inspection and placed in 'special measures'. 
At the other end of the spectrum it became harder to achieve the 'outstanding' grade, with designation only possible if the teaching and performance management of staff in the school was judged outstanding.

The final part of Sir Michael's new approach was to reduce the notice of inspections, previously up to three weeks' notice of an inspection for schools and FE colleges and eight weeks for initial teacher education providers. In all cases this was reduced to two working days.

The package as a whole increased the power of Ofsted over the teaching profession and set the course of action for individual school establishments across the country. Of course this gave more power to Ofsted, but there is a continuing question mark as to whether Ofsted itself is a capable organisation. In giving it wider powers, the grave concerns about consistency and quality of the inspectorate, most of whom were employed by external agencies, are ignored. ${ }^{2}$ At some point there has to be a quality assessment of Ofsted itself, given its great reach, power to intervene, and potential for such powers widely to outstrip its organisational capacity to maintain a high quality inspectorate given the burden of its own work.

\section{Free schools and academies}

The idea behind the free schools programme was to open new Academies following applications from a range of different groups, including parents, teachers and Academy chains. The expectation was that this would raise standards by increasing local choice for parents, injecting competition between local schools and encouraging innovation. The government moved fast to open 173 free schools by September 2013, with another 100 or so opening over the 2013/14 academic year. It should be said at this point that it was no surprise to most commentators when it was found that the initial capital costs of setting up free schools were much higher than expected, at $£ 6.6$ million per school, which had a detrimental impact on other aspects of the DfE capital budget (National Audit Office, 2013).

Some of the schools have been more controversial than others: a large proportion of the schools are based on a religious foundation; some are simply existing state schools that have avoided local authority reorganisation by re-opening as free schools; some are existing private schools that have decided their future viability is best served as a state-funded school. Some interesting consequences of the policy have been to give parents the power to save schools threatened by closure; and to give independent schools threatened with bankruptcy the option to be bailed out by the state.

However, the right measure of the policy is whether it is successful, not whether it is controversial. On this, it is too early to say whether the free schools will be either popular or effective. Early intakes have been relatively small, but this is often because they are approved too late to take part in the Common Application Process to schools. Their intakes are typically the slightly less deprived and more able in the neighbourhoods from which they recruit (Green et al., 2015).

Ofsted judgements of the few that have been inspected so far have been positive, on average, although two have been judged as ineffective and two have closed as a result.

Whilst the free schools programme has been the highest profile education policy of this government, the process to encourage or force schools to become academies, independent of local authority control, has been far greater in scale and impact. Initially, the possibility of conversion was restricted to schools judged as outstanding by Ofsted but it was later extended to all schools who could prove capable of doing so. The Department for Education has been accused of bribing schools with one-off payments outside their funding allocation to convert to academy status (Cusick and Garner, 2013). More importantly, re-occurring financial advantage to many converting came in 
the way in which the DfE reallocated the money currently retained by local authorities to support their maintained schools (LACSEG). This is because new academies were given a share of this figure on a per pupil basis, even though local authorities heavily use the cash to support schools with high pupil mobility and levels of disadvantage. The calculation of the overall local authority budget was also incorrect in a number of cases (Cook, 2013).

There has been forced conversion of a number of schools to academy status following poor Ofsted ratings (Wormald and Lauener, 2012). These schools were given new academy sponsorship, often against the will of the parents and teachers in the schools themselves. This can be seen as a minor modification of the policies of the preceding Labour government, who used academy sponsorship as a way to turn around failing schools, but did so with local authority consent.

\section{Teacher performance related pay}

The enthusiasm for performance related pay for complex white collar jobs with ill-defined outputs is one of curiosity to many economists, given how rarely it is backed up with evidence that it works (see, e.g. Lavy, 2009; Fryer, 2013). However, pay flexibility is appealing to governments who act as monopsony wage setters since it holds the possibility of retaining the most talented staff through pay incentives without substantially increasing the pay burden overall.

Headteachers and governing bodies were not lobbying for new pay reforms. Some may have been ideologically opposed to performance related pay, but many more felt that pay flexibility has always been quietly possible through the use of existing pay increments and responsibility points. More importantly, they are nervous about implementing such a reform fairly without reliable measures of teacher quality, and of undermining a team culture and sense of common purpose within their schools.

Nevertheless, from September 2013 schools were required to revise their pay and appraisal policies to link pay progression to teacher's performance in their school. They could do this in order to recruit and retain excellent teachers or to target need in certain subjects. It is still too early to say what type of schemes schools will introduce, let alone what impact they might have, but it is hard to see high-powered, sophisticated performance related pay schemes being introduced by more than a handful of schools.

\section{Teacher training}

The government perceived two major problems with teacher training: (1) the quality of the applicants to teacher training was not high enough and individuals with poor academic credentials were entering the profession; (2) the training itself did not adequately prepare for the realities of teaching in schools.

Their response to the first problem was to require that new graduates have at least a 2:2 in their undergraduate degree to get state-funded training and to remove maintenance grants for almost all (except those with a good degree training in a shortage subject). This was not a particularly logical response and may in fact lower the supply of high quality trainees for several reasons. Firstly, we require a fairly fixed and predictable number of people to train to be teachers each year. Restricting eligibility requirements does not increase the number of applicants with good academic credentials, unless it uncovers a surfeit of labour previously unwilling to apply because entry was not prestigious enough.

Secondly, we know very little about how to identify those with potential to be good teachers before they try it out, and we are quite certain that degree class is a poor proxy for potential (Slater et al., 2012). So the tightening of academic entry requirements into teaching is not helpful: it will restrict 
the quantity of recruits and have no impact at all on average teaching effectiveness. A better policy is to recruit a broader pool of trainees to try out teaching for a short time and to incentivise teacher training institutions to drop trainees from their programmes as evidence accumulates on their suitability for the profession. By contrast, it is still the case that almost everyone can pass a teacher training course because these institutions are judged on completion rates and progression into the profession.

Thirdly, replacing maintenance grants for trainees with student loans barely reduces the costs to the government of teacher training. This is because the typical teacher, if he or she remains in the profession, may never earn enough to repay the loans associated with teacher training (depending on how the repayment threshold is raised over time) (Allen et al., 2014). It is nevertheless likely to act as a financial deterrent for some. A more attractive policy would be to declare the fee and maintenance costs as zero, provided an individual teaches in the state maintained sector for (say) four years, introducing a repayment plan for those who leave to work in private schools or in other industries.

It is not yet clear whether the training subsidy reforms will cause a deterioration in the quality of the pool of applicants to teacher training. They were introduced against the backdrop of high graduate unemployment and so application rates to the profession have held up. The combination of rising pupil rolls creating increased demand for teachers and the economic recovery providing alternative employment opportunities may produce a teacher supply crisis in the next few years.

The government responded to the very real concerns of both schools and former trainees that the Post Graduate Certificate in Education left them ill-prepared for the classroom by declaring that they wanted the majority of the profession to learn the 'craft' of teaching directly from teachers. Their new school-based training route called School Direct took its first (very small) intake in September 2012. Participating schools (or groups of schools) took responsibility for designing and delivering a one-year programme leading to Qualified Teacher Status.

However, in September 2014 the statistics revealed that just 61 per cent of School Direct places were filled this year; 6,451 of the 11,335 fee-paying places allocated and 2,781 of the 3,919 salaried places. This compares to 90 per cent of university places. Last year 68 per cent of School Direct places were filled (Ward, 2014). These shortfalls will start to create a very significant teacher supply crisis if they are allowed to accumulate against a rising need for teachers.

It would seem that policymakers correctly identified a problem with institution-based training, but misjudged the solution. Schools themselves may feel that newly qualified teachers are not adequately prepared but they lack the capacity to devise and manage teacher training themselves. The government should have anticipated this: the existing school-led routes (GTP and SCITT) were widely lauded but remained small. The education system finds itself with a free-rider problem where every school would like somebody else's school-trained teacher. Teach First has developed a small but successful school-based training route. However, signing up schools to the programme remains the greatest constraint on its growth and many of their schools in very deprived areas join to overcome recruitment difficulties. Moreover, Teach First offers considerable support to the schools involved in the programme.

On the potential trainee side, it is not difficult to imagine why School Direct is struggling to fill places. It could be that trainees feel safer training in an institution that gently exposes them to teaching, or perhaps it is unrealistic to ask applicants to choose and apply directly to schools given they are unlikely to know anything about what type of school might suit them. 


\section{Protecting poorer students from a harsh budgetary climate}

Over the course of this government, education has suffered its largest real-term funding cuts since the 1950s (Chowdry and Sibieta, 2011). These cuts have been greatest in higher education, post-16 education, early years and youth services, and on capital spending. By contrast, schools have been relatively well-protected because almost the entire budget is spent on staff and it is unpalatable to pass costs onto children and their families.

\section{Higher education}

Higher education is the sector that has suffered least, and arguably gained, from austerity. The higher education finance regime introduced in September 2012 allowed universities to set variable tuition fees, which largely offset cuts to government funding. The government chose to increase fees from $£ 3,290$ to $£ 6,000$, with an upper cap on tuition fees at $£ 9,000$ per year from 2012. Most universities have decided to charge the full $£ 9,000$ and to compete for students on reputation and quality, rather than on price. At these levels, many courses with lower delivery costs in the arts and humanities have become almost entirely funded by student borrowing rather than the taxpayer. However, this new system is still costly for taxpayers because the government's estimate of the portion of loan outlay that will never be repaid by graduates - known as the resource accounting and budgeting (RAB) charge - has risen steadily from an initial 28 per cent to 45 per cent, very close to the level at which there will have been no savings to the public purse from the trebling of free and the slashing of direct grant (Morgan, 2014). Alongside these reforms, some attempt at further liberalisation of the market took place, with universities exempt from the old rules capping student numbers for students who achieved high grades (at least AAB).

The government has changed the terms under which students from low income backgrounds are supported through university. The National Scholarship Programme replaced the minimum statutory bursary and universities can use it to provide financial support in the form of fee waivers, cash bursaries, and subsidised goods and services. However, because universities have received the funding in relation to their size rather than the socioeconomic make-up of their student body, lower-ranked institutions have seen a fall in the amount of support they can offer on a per-student basis (Chowdry et al., 2012a).

The interesting aspect of these higher education policy reforms is that despite all the controversy, particularly over the Liberal Democrat pledge, the new funding regime is actually more progressive than its predecessor. The poorest 29 per cent of graduates will be better off under the new system and the richest 15 per cent of graduates will pay back more than they borrow. This means that prospective students from poorer backgrounds should not be discouraged by the scheme, unless they are debt averse or do not receive clear information about the likely costs and benefits of going to university (Chowdry, 2012b).

\section{Post-16 education}

Further education has suffered deep cuts over the course of this government, with predictably little publicity or public disapproval. In 2010 the FE budget was cut by $f 1.1$ billion ( 25 per cent) and in June 2013 another $f 230$ million of cuts were announced. It has since been announced that the Adult Skills Budget (which funds non-academic education to the over 19s) will be cut by $£ 460$ million by 2015-16 (Elledge, 2014). The government implemented unit cost reductions in the 16-19 participation budget and removed support provided by the Education Maintenance Allowance (EMA), a programme of conditional cash transfers that had increased post-compulsory participation rates (Dearden et al., 2009). 
Critics of EMA had pointed out its large deadweight loss because most (88 per cent) recipients would have chosen to attend a post-16 institution without being paid to do so. However, IFS estimates that wage gains would outstrip payment costs obviously accounted for this (Chowdry and Emmerson, 2010). Participation in education by 16-18 year olds in England has indeed fallen for the first time since 2001 (DfE, 2013a).

\section{Early years}

The government has also cut early years funding. There are 581 fewer Children's Centres under this government: 3,019 in 2014; 3,361 in 2010 (Directgov, 2014). Added to this, the government, in 2013, made a controversial announcement that they intended to relax childcare ratios in early years settings. The rationale was that the sector was stuck in a low quality cycle where per child costs were almost prohibitively high to parents, despite very low sector wages, as a result of worker-child ratios. By introducing more stringent entry requirements to the profession in the form of early years qualifications, the new more highly trained workers would be able to cope with more children per worker and would be able to receive a higher wage for doing so (DfE, 2013b). The idea of the imposition of tougher entry requirements that are almost certainly unrelated to worker quality mirror those introduced for teacher training and so all the same criticisms apply here. These reforms were said to mirror policy in France, a country not noted by DfE research for its high quality childcare (Pascal et al., 2013). However, the reforms to the ratios hit a political buffer when the Liberal Democrats, with the credit taken by the Deputy Prime Minister, intervened to kill off the policy.

The most disadvantaged 2-year-olds can now receive up to fifteen hours a week of fully funded childcare (on the same terms as all 3-year-olds do). Just a month after the start of the programme an impressive 70 per cent of eligible children were taking up places, although there are problems with supply of high quality places for this age group (DfE, 2013c).

\section{Capital spending}

Early cuts by Parliament to capital spending on schools, including the cancellation of the Building Schools for the Future programme, could not have come at a worse time - with rapidly rising demand for school places in the primary sector. A failure by the Office for National Statistics to reflect a rising birth rate since 2001 in its population projection until 2008 meant that the Department for Education failed to plan for a new schools building programme and local authorities continued to remove surplus places in schools (removing 5 per cent of places between 2004 and 2010) (HoC, 2013). Furthermore, part of this reduced capital budget has been used to build new free schools in areas where additional capacity is not needed.

\section{Schools}

Schools current spending has been relatively well protected from budgetary cuts, not least because cuts are very difficult to achieve when almost all expenditure goes on wages. However, teachers have been subject to 1 per cent pay rises, well below the rate of inflation, and changes to their pension arrangements from 2015 are equivalent to a 3 per cent pay cut.

Against this background of falls in overall education funding, the government has made the first moves towards removing the role of local authorities in the distribution of school funds through the establishment of a national funding formula. The idea is that eventually each school's funding will be calculated centrally with only limited discretion for local authorities to vary funding around these levels. However, given the huge variation in funding that currently exists, it is almost impossible to achieve this in an environment of funding freezes (Allen et al., 2012). So, as a first stage, the Department for Education now places restrictions on the items that can be included in a 
local authority's own funding formula. The idea is that through the gradual tightening of these restrictions, similar schools in different local authorities will see their budgets converge.

Schools serving more deprived areas have been well protected from funding cuts by the pupil premium policy, which distributes $£ 2.5$ billion of the (existing) education budget to schools at an initial rate of $£ 600$ per disadvantaged pupil (HMT, 2010). This amount may seem relatively generous, but it is actually a fraction of the implied additional income $(£ 2,460$ for primary and $£ 3,370$ for secondary) that schools already received for each pupil eligible for free school meals through local authority formulas (Chowdry et al., 2010).

The government hoped that this innovation would encourage schools to take on poorer pupils as well as to devote resources to raising attainment. There is very little consensus on how resources are best spent to improve school quality and there is, of course, no way of judging whether the money has been spent effectively or whether this is a worthwhile exercise.

One of the strangest announcements of the Parliament has been the Liberal Democrat claimed initiative to provide free school meals to all infants. It has been very difficult for many schools to implement since many primary schools have no kitchen. However, the evidence on pilots of this policy has been marginally positive (Kitchen et al., 2012). Whether it is the best way to spend in the education system the headline $f 1 b n$ of marginal funds used in the announcement is a point for debate.

\section{Concluding remarks}

In many respects this government has taken a well evidenced and moderate approach to reforming the education system against the very difficult backdrop of funding restraints. However, it has often done so in a way that is felt to be publicly humiliating for those involved in delivering education, from teachers through to teacher trainers and local authorities. This is unwise in a sector where the productivity of the workforce is so tightly bound to their sense of purpose and motivation.

Libertarian instincts to let market forces improve the system have been rather overridden by the centralising tendencies of a Secretary of State with an exceptionally clear vision. Moreover, by removing power from existing devolved institutional structures it has been passed across to a small network of organisations - Ofsted as the sole arbiter of quality, the New Schools Network which helped free schools to open, the Educational Endowment Foundation which reports on which classroom practice is effective and, most importantly, the office of the Secretary of State itself. This leaves open the question of how well a system can function when those who are given power do not have clear accountability and consequences for their own mistakes and shortcomings. In this new system without local authorities delivering services, who has the capacity to intervene to manage the system in times of change and when things go wrong?

Future governments are unlikely to reverse most reforms but two major issues will have to be addressed in the next parliament. First, how can a decentralised school-based teacher training system deliver sufficient numbers of new teachers as the economy recovers? Teacher supply is not a problem that can be deferred or ignored, so we may see financial incentives for schools to join School Direct or a partial retreat back to university-led provision.

Second, who makes sure the schooling system delivers the right quality and quantity of pupil places in an entirely devolved system without local authority control? There has been, belatedly, recognition that a 'middle tier' of oversight is needed and power has been ceded to new Regional Schools Commissioners, who will pick new free schools bids and who are judged on the number of 
schools they persuade to convert to academy status. However, the regulation is still a mess: local authorities have a duty to provide enough places, without the capacity or control to do so.

\section{Footnotes}

1. For a fascinating ongoing commentary into the workings of the political team in DfE over that period Dominic Cummings provides an enlightening viewpoint at http://dominiccummings. wordpress.com/.

\section{References}

Allen, R., Belfield, C., Greaves, E., Sharp, C. and Walker, M. (2014), The Costs and Benefits of Different Initial Teacher Training Routes, IFS Report R100, available at www.ifs.org.uk/publications/7435.

Allen, R. and Burgess, S. (2010), The Future of Competition and Accountability in Education, 2020 Public Services Trust at the RSA report.

Allen, R. and Burgess, S. (2011), 'Can school league tables help parents choose schools?', Fiscal Studies, 32(2), pp. 245-61.

Allen, R. and Burgess, S. (2013), 'Evaluating the provision of school performance information for school choice', Economics of Education Review, 34, pp.175-90.

Allen, R., Burgess, S., Rasul, I. and McKenna, L. (2012), Understanding School Financial Decisions, Department for Education Research Report RR183.

Chowdry, H., Dearden, L., Goodman, A. and Jin, W. (2012), 'The distributional impact of the 2012-13 higher education funding reforms in England', Fiscal Studies, 33(2), p.211-36.

Chowdry, H., Dearden, L., Wenchao, J. and Lloyd, B. (2012), 'Fees and student support under the new higher education funding regime: what are different universities doing?', IFS Briefing Note BN134.

Chowdry, H. and Emmerson, C. (2010), 'An efficient maintenance allowance?', IFS Observations, available at www.ifs.org.uk/ publications/5370.

Chowdry, H., Greaves, E. and Sibieta, L. (2010), 'The pupil premium: assessing the options', IFS Commentary 113.

Chowdry, H. and Sibieta, L. (2011) 'Trends in education and schools spending', IFS Briefing Note BN121.

Cook, C. (2013), 'Academies overpaid in funding blunder', Financial Times, 9 January.

Cusick, J. and Garner, R. (2013), 'Cash for academies: Michael Gove 'bribes' schools to change their status', The Independent, 13 February.

Dearden, L., Emmerson, C., Frayne, C. and Meghir, C. (2009), 'Conditional cash transfers and school dropout rates', Journal of Human Resources, 44(4) pp. 827-57.

Department for Education (2013a), National Curriculum, available at www.gov.uk/government/collections/national-curriculum. -(2013b), 'Participation in education, training and employment by 16-18 year olds in England', Statistical First Release SFR 22/2013.

Department for Education (2013c), More Great Childcare: Raising Quality and Giving Parents More Choice, London, The Stationery Office Ltd. 
Department for Education (2013d), '92,000 2-year-olds already receiving free childcare', Press release 11/11/2013 available at www.gov.uk/government/ news/92000-2-year-olds-alreadyreceiving-free-childcare.

Directgov (2014), 'Sure Start Centres', available at childrenscentresfinder.direct.gov.uk/snapshotchildrens-centre.

Elledge, J. (2014), 'Why don't we care that the further education budget has just been cut by 20 per cent', New Statesman, 14 February, available at: www.newstateman.com/lifestyle/2014/02/ whydont-we-care-further-education-budget-has-been-cut-20- cent.

Fryer, R. (2013), 'Teacher incentives and student achievement: evidence from New York City public schools', Journal of Labor Economics, 31(2), pp. 373-427.

Green, F., Allen, R. and Jenkins, A. (2015), 'Are free schools socially selective? A quantitative analysis', British Educational Research Journal (forthcoming).

HM Treasury (2010), Spending Review 2010, London, The Stationery Office Ltd.

House of Commons Committee of Public Accounts (2013), Department for Education: Capital funding for new school places, Twelfth Report of Session 2013-14, London, The Stationery Office Ltd.

Kitchen, S., Tanner, E., Brown, V., Payne, C., Crawford, C. Dearden, L., Greaves, E., and Purdon, S. (2012), Evaluation of the Free School Meals Pilot, Department for Education Research Report RR227.

Lavy, V. (2009), 'Performance pay and teachers' effort, productivity, and grading ethics', American Economic Review, 99(5), pp.1979- 2011.

Morgan, J. (2014), 'RAB charge debate will 'perplex' future generations, says Willetts', Times Higher Education, 29 May, available at http://www.timeshighereducation.co.uk/news/ rab-charge-debatewill-perplex-future-generations-says willetts/2013615.article

National Audit Office (2013), Department for Education: Establishing Free Schools, London, The Stationery Office.

Pascal, C., Bertram, T., Delaney, S. and Nelson, C. (2013), A Comparison of International Childcare Systems, DfE Research Report RR269.

Slater, H., Davies, N. and Burgess, S. (2012), 'Do teachers matter? Measuring the variation in teacher effectiveness in England', Oxford Bulletin of Economics and Statistics, 74(5) pp. 629-45.

Ward, H. (2014), 'Teacher supply crisis feared as School Direct struggles to fill places', Times Educational Supplement, 27 November, https://news.tes.co.uk/b/news/2014/11/27/teacher supplycrisis-feared-as-two-in-every-five-school-direct-places left-unfilled.aspx.

Wolf, A. (2011), Review of Vocational Education - The Wolf Report, https://www.gov.uk/government/uploads/system/uploads/ attachment_data/file/180504/DFE00031-2011.pdf.

Wormald, C. and Lauener, P. (2012), Written Evidence from the Department of Education and the Education Funding Agency, Public Accounts Committee Evidence HC787, available at www.publications.parliament.uk/pa/cm201213/cmselect/cmpubacc/787/787we02.htm. 